\title{
Strategic policy of companies in the area of social responsibility: Covid-19 challenges
}

\author{
Svetlana Drobyazko ${ }^{1 *}$, Tetiana Hilorme $^{2}$, Dmytro Solokha ${ }^{3}$, and Oksana Bieliakova ${ }^{4}$ \\ ${ }^{1}$ Doctor of Economic Sciences, Professor, President European Academy of Sciences, 71-75 Shelton \\ Street Covent Garden, London, United Kingdom. \\ ${ }^{2}$ Oles Honchar Dnipro National University, Ukraine. \\ ${ }^{3}$ Donetsk State University of Management, Ukraine. \\ ${ }^{4}$ Azov Maritime Institute of the National University "Odessa Maritime Academy", Ukraine.
}

\begin{abstract}
COVID 19 is a litmus test for TNCs in the field of social responsibility. A scientific and methodological approach to determining the level and activation of corporate social responsibility (CSR) of business in the national economy in the form of a three-dimensional matrix model of positioning the level of development of CSR of business units in the coordinate system: social, environmental and economic components of CSR has been developed. The methods used in the study, the construction of the Gibbs Triangle and the method of taxonomy to determine the most influential aspects of GRI reporting (G4), allowed to propose a CSR monitoring system for key business performance indicators. The results of the analysis of this study allow distinguishing five areas of responsibility: the necessary level of responsibility - for statutory obligations, the developed level - active charitable and sponsorship, high level responsibility to internal and external stakeholders, strategic - focus on the social investment state level, as well as synergetic - a comprehensive combination of all components of the CSR. In conclusion, the level and activation of corporate social responsibility of industrial enterprises in the form of a three-dimensional matrix model of positioning the level of development of business units in the coordinate system: social, environmental, and economic components, has been determined to develop alternative scenarios to justify management decisions.
\end{abstract}

\section{Introduction}

The development of the world economy at the beginning of the XXI century is characterized by increasing turbulence and the recovery of the development's cyclical crisis component. At the turn of the third millennium, a new economic reality emerged characterized by profound shocks caused by a large number of new phenomena and processes, such as the comprehensive transformation of economic systems, the formation of the post-industrial information society, knowledge economy, education, the economics of change caused by globalization, informatization, computerization, etc.

* Corresponding author: svetlana.drobyazko@yahoo.com 
COVID-19 was a litmus test for TNCs in the area of social responsibility. The militarybased economy directly affects private business: companies are refocusing production, changing approaches to customers, and simply trying to help the state and ordinary people.

According to UN studies' data, the crisis unfolding worldwide will "eat" $6.7 \%$ of working time already in the second quarter of 2020 [2]. In terms of "people," this is equal to 195 million workers who will soon lose their jobs [21]. Additionally, add about 40 million already unemployed in the world since the beginning of 2020 [10]. The most massive job cuts are expected in the Arab world, Europe, and the Asia-Pacific region. Among the sectors that will be most affected, the leaders of world organizations list the hotel and tourist and restaurant sectors, retail, industry, business, and administrative activities $[12,18]$.

To minimize social and economic impacts, companies of all forms of ownership must quickly implement innovative solutions to continue their operations, protect their employees, and prepare for recovery. Among the necessary guarantees of addressing the acute effects of the crisis, world leaders cite trilateral agreements between governments, organizations of employers and workers on support packages, and social dialogue. And the support packages themselves should be developed based on the principle of justice. For example, business worldwide provides financial assistance, purchases equipment for hospitals, becomes a volunteer, refocus production, waive bonuses, and surcharges in favor of others. And most importantly, it operates, pays taxes and wages, develops production capacities, explores new niches, and readjust business processes. In short, it holds the economy on its shoulders like Atlantis.

However, COVID-19 significantly "corrected" the basic principles of world production. Business is already forced to review strategies, reduce supply chains, optimize staff. So far, the focus of social responsibility is, of course, shifted to confronting the pandemic. According to a study by the U. S. Chamber of Commerce, $64 \%$ of companies are willing to assist society for protection against COVID-19, of which third - financial assistance [19]. Others are willing to help with equipment and products (too vulnerable groups of the population) and become volunteers (information support, IT, consulting, and legal services) [20].

The business is trying to retain staff. This is the basis of business, so it retains staff and business restructuring that will prioritize CSR strategies (corporate social responsibility). There will be many changes in labor practices: staff relations and recruitment will be transformed; they will talk in a new way about the balance between personal and working life because we have to get used to working remotely; new staff training systems will appear.

Companies should already pay attention to the staff's well-being, mental health (when the boundaries between work and personal life are blurred), and whether their employees suffer from domestic violence [22]. All of the above is nothing more than talk about social responsibility: government - to society and business, society - to the state, business - to its citizens. Corporate social responsibility is recognized as a necessary condition for business continuity. And it is also being tested for honesty. Exactly this way, as until recently, many of the CSR practices were purely declarative or image-based. But now, it is not the time for declarations, but real actions.

This is especially the case in the pharmaceutical industry. Along with health care, the pharmaceutical industry is at the forefront of the global fight against the pandemic. In addition to opening up new opportunities for pharmaceuticals in the fight against COVID19 , such as vaccine development and clinical trials of existing drugs for the treatment of COVID-19 (repurposing), the pandemic has deeply affected supply and distribution chains in the industry and posed significant risks to activities not related with the treatment of COVID-19. 
However, pharmaceutical companies' research activities in areas not related to COVID19 will slow down significantly under the pandemic's influence. Most clinical studies have had to be suspended because of quarantine restrictions, which will slow the launch of new drugs [17]. First of all, these changes will slow down the development of the Chinese pharmaceutical industry, which in recent years has significantly actively developed and has already seriously competed with the pharmaceutical industries of the USA and the EU. Because health facilities in China dealt mainly with COVID-19 patients, many studies have been suspended. This immediate narrative requires the activation of scientific research in risk management in various fields of activity to form the new paradigm of protecting society in conditions of turbulent changes, especially in corporate social responsibility.

These latest global challenges lead to the need to rethink the principles of corporate social responsibility of business, especially in the social sphere. Today, businesses require the state to support activities due to the influence of COVID-19, obtaining tax benefits and vacations, prolonging loan repayments, receiving subventions, etc. At the same time, not only big business is able to support society in the waves of COVID-19 but also small and medium-sized businesses to support employees: to do work on the "remote" principle, to provide financial assistance and more.

\section{Method}

We will carry out the comparative analysis of the definition of the level of development of CSR based on the research of the non-financial reporting in the area of stable development (construction of the Gibbs triangle) and the analysis of the reporting of companies by the GRI G4 system. The sequence of analysis of the definition of the development of companies' corporate social responsibility is shown in Table 1.

Table 1. Stages of research on the level of development of corporate social responsibility of companies.

\begin{tabular}{|c|c|c|}
\hline Stage & Name & Content \\
\hline 1. & $\begin{array}{l}\text { Analysis of } \\
\text { input data }\end{array}$ & $\begin{array}{l}\text { Make a list of non-financial reports, look for } \\
\text { electronic versions of reports, accumulate data for } \\
\text { direct analysis. }\end{array}$ \\
\hline 2. & Content analysis & $\begin{array}{l}\text { Automated keyword counting } \\
\text { Remove repetitions (duplications, mentions in } \\
\text { headings, diagrams, captions, and footnotes) } \\
\text { Manual selection according to the context }\end{array}$ \\
\hline 3. & $\begin{array}{l}\text { Data array } \\
\text { creation }\end{array}$ & $\begin{array}{l}\text { Convert the obtained data into percentages and } \\
\text { create data tables }\end{array}$ \\
\hline 4. & Graph plotting & $\begin{array}{l}\text { Plot graphs based on the obtained data, which } \\
\text { visually reflect the situation of companies }\end{array}$ \\
\hline 5. & $\begin{array}{l}\text { Analysis of } \\
\text { results }\end{array}$ & General analysis of research results \\
\hline
\end{tabular}

The priority purpose of the study is to determine the development of corporate social responsibility based on the principles of non-financial reporting GRI and, using the method of content analysis of non-financial reporting, to explore three interrelated areas: economic, social, and environmental.

Content analysis is a CSR level measurement method that measures the level of reporting in various publications, especially in annual reports [16]. Content analysis allows using both qualitative and quantitative data analysis. This method's main advantages are that subjectively selected variables are subject to a relatively objective analysis procedure 
in the future [6-7]. Accordingly, the results of each study become independent. Another advantage of the method is its mechanistic nature, which allows for a large sample $[1,9]$. The model of the "Gibbs-Roseboom triangle" described in the article was used [17].

The three main directions of stable development are environmental, social, and economic directions. These attributes can be used to evaluate and compare the positioning of non-financial reporting. In this context, the "Gibbs triangle," also known as the "concentration triangle," "triangle diagram", or "ternary plot", allows us to visualize triple combinations (combinations of three components) in a two-dimensional environment [13$15]$.

The Gibbs triangle we have considered is a coordinate system within which a business's social responsibility is found. The triangle sides reflect the components of stable development (SD): social, environmental, or economic directions. The triangle vertices are equivalent to directions in their pure form. The axes' points are equivalent to binary combinations; points within the triangle characterize the combination of three dimensions.

From the two methods of constructing a triangle, we chose Roseboom's method, according to which a point is determined not by lines perpendicular to the sides of the triangle (as is done according to Gibbs' method) lines parallel to the sides of the triangle. All three components are $100 \%$ of a single whole, and the sum of the coordinates along the axes must be equal to the length of one of the sides of the triangle.

The farther a particular area is from the vertex, the less it is associated with the corresponding phenomenon [4]. Distances are measured by lines parallel to the triangle's side, form an angle with the axis (by the method of Rosebom discussed above). For each axis, there are three qualitative definitions: strong, partial, and weak focus.

Strong focus indicates that this area is dominant, and all other areas do not play a significant role [5]. Partial focus means that several directions will influence the area of the triangle. Soft focus implies an insignificant impact of the appropriate measurement and dominance of other areas [3].

\section{Results and discussion}

\subsection{Results}

The conducted study gave the following results. The Register of non-financial reporting's pharmaceutical sector at the time of the last update of content analysis data consisted of 82 reports of 20 business organizations from 2008 through 2018. This sector has a sufficient number of reports in stable development and is innovative in terms of integration and application of various tools in stable development.

In recent years, many business organizations in the pharmaceutical sector have made a smooth transition to the publication of reports in stable development and integrated reporting. The vast majority of all reports (46 out of 82 ) are positioned as "mostly social".

It should be noted that the assumptions that business organizations in the pharmaceutical sector will mainly have environmental and economic focus were not justified. However, by the set of research areas, 19 reports out of 82 can be classified as environmentally oriented. Ten reports $(12.2 \%)$ can be described as socio-environmental as they have almost no economic component. The analyzed industry's resulting data are presented graphically in the Gibbs triangle by areas in Figure 1 and Table 2.

Table 2. The industry classification of reports of business organizations: "Pharmaceutical companies" section. 


\begin{tabular}{cccc}
\hline Rank & Positioning & Number of reports, units & Percentage, \% \\
\hline 1 & Mostly social & 46 & 56.1 \\
2 & Socio-environmental & 10 & 12.2 \\
3 & Social & 8 & 9.8 \\
4 & Mostly environmental & 6 & 7.3 \\
5 & Socio-environmental & 5 & 6.1 \\
6 & Environmental-economic & 3 & 3.7 \\
7 & Mostly economic & 2 & 2.4 \\
8 & Environmental & 1 & 1.2 \\
9 & Social-environmental-economic & 1 & 1.2 \\
\hline
\end{tabular}

According to the obtained data, it can be concluded that most pharmaceutical business organizations position themselves as mostly socially-oriented. The number of reports on stable development is growing every year, but the number of corporate social responsibility reports is declining.

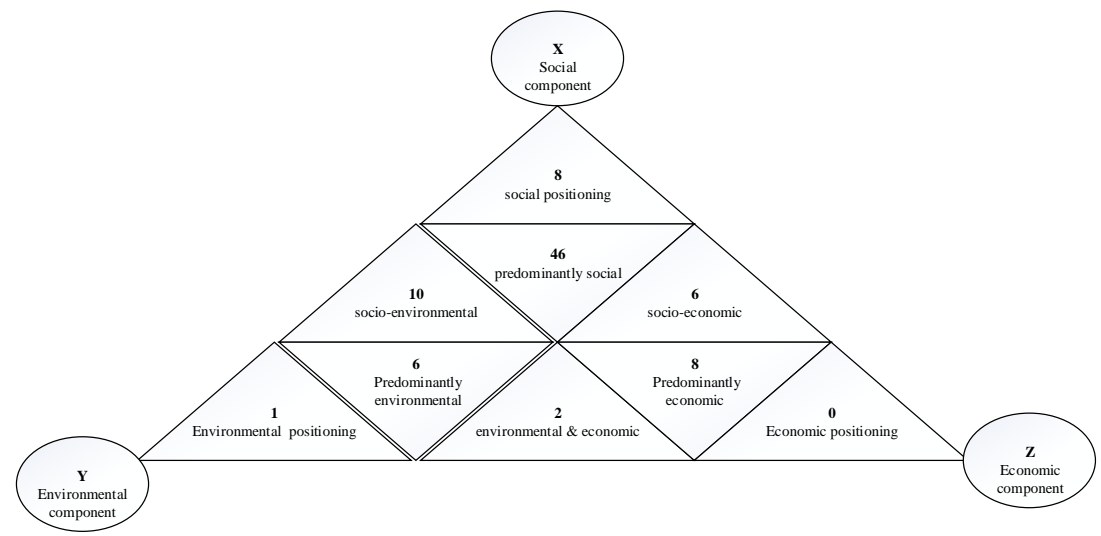

Fig. 1. Gibbs triangle by areas of CSR: pharmaceutical sector.

The conducted study on non-financial reporting of pharmaceutical business organizations contributed to a deeper understanding of established trends, actual problems, and modern transition to stable development. So, the matrix of the ratio of aspects of GRl reporting to CSR can be represented in three dimensions. 


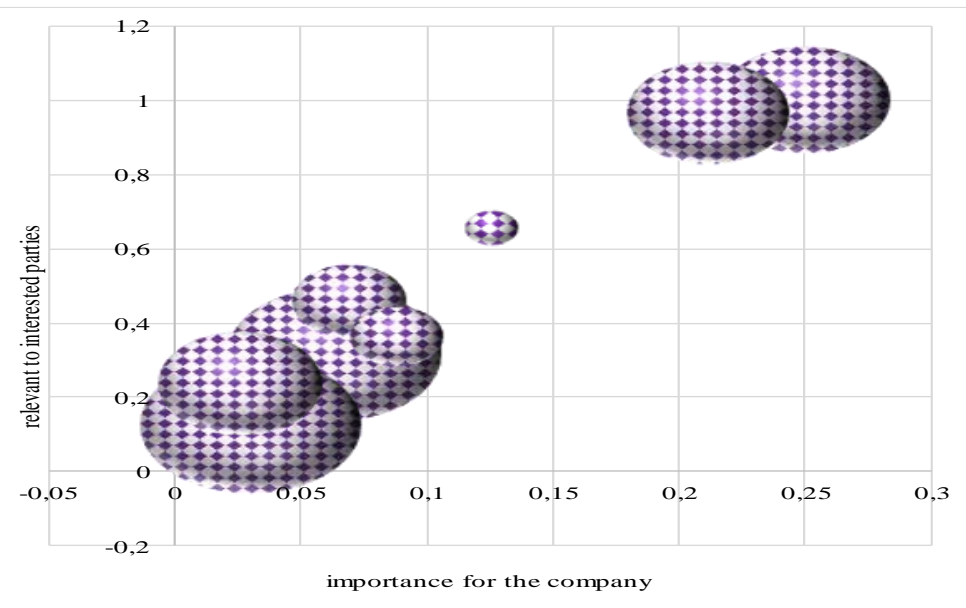

Fig. 2. Chart of the importance of aspects of the CSR of the «Bayer» company in the coordinates "Environmental component/Social component", 2018.

Each plane in sections (i; y) - social component (frontal quadrant); (i; z) - economic component (horizontal quadrant); (y; z) - environmental component (vertical quadrant) of the three-dimensional matrix of the positioning of the level of development of the CSR of a business unit is a scheme of alternatives to achieve the goals of the development of the CSR of a business unit in a specific direction. The most crucial stage in forming alternative solutions is identifying growth points that can initiate the long-term development of the CSR of a business unit. In general, each plane in one of the sections (i; y); $(i ; z)$ or (i; z) should be considered as a compromise between the interests of stakeholders and the company. An example of an analysis of the section (i; y) of the «Bayer» company is presented in Figure 2.

Figure 2 shows the actual Aspects (subjects) for stakeholders correlated with the Criteria actual for the Company in the coordinates "Environmental component/Social component". The degree of attention and scope of disclosure of certain Aspects in the CSR report is proportional to stakeholders' importance and wishes.

To analyze the CSR of a business unit's actual level of development, it is proposed to use the tools of multi-factor analysis. With the help of the constructed triangle, it is possible to determine which GRI indicators influence the development of corporate social responsibility, to determine the "bottlenecks" of the three main directions of CSR (environmental, social, economic), and to elaborate appropriate measures to develop the company in general.

A preliminary analysis conducted using the Gibbs triangle showed that only $18 \%$ of 109 non-financial reports on stable development of pharmaceutical companies in 2018 fully reflect the state of CSR. Therefore, we will conduct a multi-factor analysis of the 20 largest pharmaceutical companies. If several indicators were included in a particular aspect in the multi-factor analysis, their integral indicator was used, which was calculated using the taxonomy.

We will illustrate the proposed systematic approach using the example of the 20 largest pharmaceutical companies. According to the data, almost 50\% (22 of 45) aspects of GRI reporting (G4) are explained by more than one indicator. To conduct a multi-factor analysis, it is necessary to calculate them in advance using the taxonomy method.

The calculation of the values of all three factors for the pharmaceutical companies under study allows us to build a graphical interpretation of the integrated assessment indicator of the level of development of the CSR of business units, the theoretical form of 
which is proposed in Fig. 3. Based on the calculation of the three factors' actual value, a three-dimensional matrix of the positioning of the level of development of the CSR of the pharmaceutical companies understudy was built (Fig. 3).

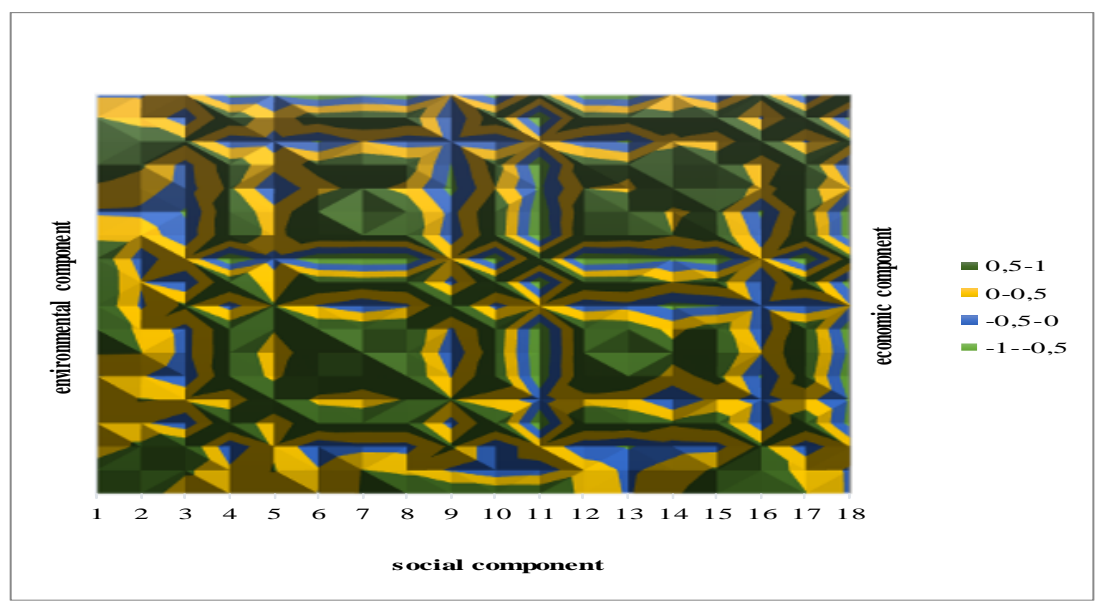

Fig. 3. Graphical interpretation of the integrated assessment indicator of corporate social responsibility according to the rating of 2018 .

The proposed scientific and methodological approach to determining the level and activation of corporate social responsibility in the form of a graphical interpretation of the integrated indicator of corporate social responsibility in the coordinate system (social, environmental and economic components) is reflected in the elaboration of economic program and development at Bayer.

The obtained new scientific and theoretical results and methodological developments on the use of energy saving tools have practical value in the direction of increasing the competitiveness of the enterprise.

\subsection{Discussion}

The most promising area, in our opinion, is to build an organizational profile of CSR, which would reflect the past, present, and future of the system of corporate social responsibility of a business and would allow us to assess the resilience of social practices.

However, it is advisable to focus not on the comparative analysis of the leading indicators of social investment, the so-called efficiency of social investment, but on assessing the management system's quality of management decisions and compliance with the best practices in this area.

The organizational profile is built through consistent accounting of assessments of experience, current status, and prospects for social responsibility development. The dynamic profile indicates companies' intentions to make social responsibility a strategic factor of competitiveness. The static profile with a relatively high individual assessment level indicates a balanced social policy and the successful practice of social investment. The regressive profile signals to management that in the future, the company may lose the benefits of stable development related to the social sphere, so special attention should be paid to investment policy, risk assessment of social investment, and harmonious development of intellectual and social capital. 
Determining the nature of the social responsibility profile using relevant criteria is the basis for monitoring corporate social responsibility for key business performance indicators. So, the proposed tool considers the dynamic specifics of the development of the social responsibility system, allows us to identify critical success factors or limitations of the state of CSR, and form judgments about its stability in the future.

Depending on the profile type (Table 3), there are proposed recommendations on improving CSR policy and approaches to implementing social investment for all groups of stakeholders.

Table 3. Recommendations on improvement of social responsibility depending on the type of organizational profile of companies.

\begin{tabular}{|l|l|}
\hline \multicolumn{1}{|c|}{ Profile type } & Recommendations depending on the type of organizational profile \\
\hline $\begin{array}{l}\text { Regressive profile - it } \\
\text { is necessary to pay } \\
\text { attention to the } \\
\text { prospects } \\
\text { development of the } \\
\text { CSR system }\end{array}$ & $\begin{array}{l}\text { The necessity to take into account investment risks for all } \\
\text { categories of stakeholders based on the proposed mechanism. } \\
\text { Development of projects that affect the development of the local } \\
\text { business community. } \\
\text { Implementation of the principles of assessing the impact of social } \\
\text { responsibility on the formation of intellectual capital }\end{array}$ \\
\hline $\begin{array}{l}\text { Progressive profile - it } \\
\text { is necessary to } \\
\text { understand the } \\
\text { experience of social } \\
\text { responsibility for its } \\
\text { practical } \\
\text { implementation. }\end{array}$ & $\begin{array}{l}\text { Ensure the necessary level of social positioning through the } \\
\text { publication of social reports following international standards. } \\
\text { of a city, region, etc.). } \\
\text { Ensure the formation of internal and external databases on the } \\
\text { experience of implementation of critical social processes }\end{array}$ \\
\hline Balanced profile & $\begin{array}{l}\text { Ensure the support for the stability of the CSR system and } \\
\text { benchmark CSR technologies }\end{array}$ \\
\hline
\end{tabular}

So, monitoring corporate social responsibility for key business performance indicators to build an organizational profile allows us to determine the actual state of the CSR in companies and propose appropriate measures to improve it.

\section{Conclusion}

The last decade has added an unprecedented systemic, integrated crisis to this list of profound changes, which expresses the instability, turbulence, variability of the modern world. The world economy is in constant turbulent motion; new threats and dangers are continually emerging. For example, COVID-19 led to the collapse of the whole world economy, the destruction of stock markets, mass unemployment, the socio-environmental threat to human existence in general.

The existing risk management mechanisms and models cannot cope with the leveling of threats at different hierarchical levels of the economy: from global to individual. There is a need to identify ways to minimize the main negative factors that may arise in human activity and especially economic ones.

Only global implementation of the model of responsibility (as a set of attributes economic, social, environmental) as a strategy for the development of society will determine risk management mechanisms. The economic crisis creates global economic problems (their emergence or intensification), and at the time of turbulence, the solution of existing problems is not possible.

Additionally, turbulence involves wave-like fluctuations in the economic situation of separate countries, which involves periodic improvements and deteriorations, and the crisis 
is characterized by a long-term recession, the consequences of which are manifested in many countries around the world.

The turbulence of the economy is a threat to both countries and the world at large because, at any time, it can turn into a crisis, the scale, and consequences of which are difficult to predict. The current global crisis of 2020 arose due to global processes, integration processes in the economic and political life of each country.

The inability of countries to create a shield to counteract the turbulent process, the existence of different poles of economic interests, the inability to live in a global world has led to the collapse of the scientific platform for research in various fields.

Modern society is developing in conditions of acute social, economic, and environmental problems. Given the ever-growing role and significant impact of business on modern society's development, corporate social responsibility (CSR) is becoming increasingly important. CSR's value is in the depreciation by companies of negative impacts of their production activities, in solving problems of global and local development, in creating an atmosphere of predictability, trust, and shared values in society. Thanks to CSR business becoming more stable in economic and social aspects, it can increase their intangible assets.

\section{References}

1. R. Albuquerque, Y. Koskinen, C. Zhang, Corporate social responsibility and firm risk: Theory and empirical evidence. Management Science, 65 (10), 44514469, (2019)

2. R. M. Anderson, H. Heesterbeek, D. Klinkenberg, T. D. Hollingsworth, How will country-based mitigation measures influence the course of the COVID-19 epidemic? The Lancet, 395 (10228), 931-934, (2020)

3. J. Cao, H. Liang, X. Zhan, Peer effects of corporate social responsibility. Management Science, 65 (12), 5487-5503, (2019)

4. E. Chen, G. Zhang, T. Fu, An Empirical Study on Population Capacity of Urban Land in Macao. In 2016 2nd International Conference on Economy, Management, Law, and Education (EMLE 2016).

5. J. Cui, H. Jo, H. Na, Does corporate social responsibility affect information asymmetry?. Journal of Business Ethics, 148 (3), 549-572, (2018)

6. S. Drobyazko, A. Barwińska-Małajowicz, B. Ślusarczyk, L. Zavidna, M. DanylovychKropyvnytska, Innovative Entrepreneurship Models in the Management System of Enterprise Competitiveness. Journal of Entrepreneurship Education, 22, Issue 4, (2019)

7. S. Drobyazko, O. Bondarevska, D. Klymenko, S. Pletenetska, O. Pylypenko, Model for forming of optimal credit portfolio of the commercial bank. Journal of Management Information and Decision Sciences, 22 (4), 501-506, (2019)

8. A. Durmanov, V. Bartosova, S. Drobyazko, O. Melnyk, V. Fillipov, Mechanism to ensure sustainable development of enterprises in the information space. Entrepreneurship and Sustainability Issues, 7 (2), 1377-1386, (2019)

9. A. Dyck, K. V. Lins, L. Roth, H. F. Wagner, Do institutional investors drive corporate social responsibility? International evidence. Journal of Financial Economics, 131 (3), 693-714, (2019)

10. J. W. Goodell, COVID-19, and finance: Agendas for future research. Finance Research Letters, 101512, (2020) 
11. Z. H. A. N. G. Guaili, Y. A. N. Jun, A. I. B. Guangdong, An Empirical Study on Population Carrying Capacity of Urban Land in Guangzhou. Natural Resource Economics of China, (6), 9, (2017)

12. H. He, L. Harris, The Impact of Covid-19 Pandemic on Corporate Social Responsibility and Marketing Philosophy. Journal of Business Research, (2020)

13. T. Hilorme, I. Perevozova, A. Sakun, O. Reznik, Ye. Khaustova, Human Capital as a Factor in the Implementation of Energy-Saving Technologies. Proceedings of the 34 the International Business Information Management Association Conference, IBIMA 2019: Vision 2025: Education Excellence and Management of Innovations through Sustainable Economic Competitive Advantage. 13-14 November 2019, Madrid, Spain. pp. 9452-9460, (2019)

14. T. Hilorme, I. Perevozova, A. Sakun, O. Reznik, Ye. Khaustova, Accounting Model Of Human Capital Assessment Within The Information Space Of The Enterprise. Academy of Accounting and Financial Studies Journal, 24, Issue 3, (2020)

15. T. Hilorme, K. Tkach, O. Dorenskyi, O. Katerna, A. Durmanov, Decision making model of introducing energy-saving technologies based on the analytic hierarchy process. Journal of Management Information and Decision Sciences, 22(4), 489-494, (2019)

16. D. Jamali, C. Karam, Corporate social responsibility in developing countries as an emerging field of study. International Journal of Management Reviews, 20 (1), 32-61, (2018)

17. A. Kıymalığlu, Impact of Digital Transformations on Corporate Social Responsibility (CSR) Practices in Turkey: A Study of the Current Environment. In Digital

Transformation and Innovative Services for Business and Learning (pp. 102-118). IGI Global, (2020)

18. A. Kleine, M. Von Hauff, Sustainability-driven implementation of corporate social responsibility: Application of the integrative sustainability triangle. Journal of Business Ethics, 85(3), 517, (2009)

19. L. M. Koonin, Novel coronavirus disease (COVID-19) outbreak: Now is the time to refresh pandemic plans. Journal of business continuity \& emergency planning, 13 (4), $1-15,(2020)$

20. T. Laing, The economic impact of the Coronavirus 2019 (Covid-2019): Implications for the mining industry. The Extractive Industries and Society, (2020)

21. M. Nicola, Z. Alsafi, C. Sohrabi, A. Kerwan, A. Al-Jabir, C. Iosifidis, ..., R. Agha, The socio-economic implications of the coronavirus and covid-19 pandemic: A review. International Journal of Surgery, (2020)

22. J. You, J. Guan, C. Noronha, Corporate Social Responsibility Reporting in the Gambling Industry: Interaction With Government. In Handbook of Research on Accounting and Financial Studies, pp. 321-342. IGI Global, (2020) 